8. Супрун Л. Концепт «держава» як ключовий у мовній ментальності Д. Донцова-вісниківця. Образ. 2011. Вип. № 12. С. 30-42.

9. Цуканова Г. Карикатурна стилізація інформаційної графіки. Наукові записки Інституту журналістики. 2012. Том. 48. Липень вересень. С. 92-97.

DOI https://doi.org/10.30525/978-9934-26-042-1-41

\title{
ПРОМОЦІЯ УКРАЇНИ В СВІТІ ЧЕРЕЗ ЦИФРОВІ МЕДІА
}

\author{
Широкова I. A. \\ студентка магістратури \\ Інститут журналістики Київського університету \\ імені Бориса Грінченка \\ м. Київ, Україна
}

Оцифрування є актуальною темою не лише для українських, а й для міжнародних медіа. Зокрема у контексті змін, які відбулися у всьому світі через поширення вірусу COVID-19, постає необхідність поширювати інформацію про Україну в цифровому форматі.

Тенденції поступового переходу друкованих медіа у цифровий формат, а також особливості цифрового формату медіа у контексті різних видів людської діяльності вивчали та аналізували такі дослідники: Стратонова Н.О. [2], Манович Л.3. [3], Бодрухіна Т.А. i Манич Н.Є. [1] та інші.

Цифровий формат відкриває переваги, яких раніше не було у друкованих медіа. Одним 3 головних критеріїв $\epsilon$ його гнучкість [3, с. 49], що дає можливість постійно оновлювати інформацію відповідно до поточних змін та потреб. Таким чином, завдяки цифровій промоції подаватиметься лише актуальна інформація, яка швидко поширюватиметься серед іноземної аудиторії.

В Україні цифрова промоція була реалізована й на державному рівні, вона знайшла своє відображення у вповадженій ініціативі «Концепції розвитку цифрової економіки та суспільства України на 2018-2020 роки».

Набуло поширення практики використання владними інституціями можливостей цифрового простору: запуск інформаційних роликів, як на День Незалежності України у 2020 році, який був створений під офіційним брендом нашої держави - «Ukraine Now». Аналогічні кроки 170 
можуть використовуватися й надалі українськими цифровими медіа, скориставшись перевагою цифрового формату різнопланової подачі матеріалу.

Перелік англомовних видань про Україну $є$ доволі обмеженим: серед відомих медіа, які представлені у цифровому вигляді, «What's On Kyiv», «Kyiv Post» та «Ukrainian Journal», а також «Ukraine Business Online» $\mathrm{i}$ «Lviv Today».

Водночас коло подібних видань може бути розширене, з огляду на те, що іноземні читачі звикли до широкого вибору. Крім того, розширення кількості англомовних цифрових медіа зумовило б процес появи спеціалізованих медіа з визначеною аудиторією та відповідними комунікаційними підходами до неї.

Україна крок за кроком освоює можливості цифрового простору для комунікації всередині країни та іноземними державами ззовні. Нині існує потреба у формуванні переліку цифрових видань, 3 яких представники міжнародної читацької аудиторії отримували б інформацію відповідно до своїх потреб. Можливості цифрового формату, зокрема різноманітність варіантів у подачі інформації, розширюють перспективи діяльності українських цифрових медіа у реалізації творчих ідей. Процес інтеграції як існуючих так і нових медіа у процес оцифрування інформації у межах світових тенденцій доповнив би сучасний цифровий простір українським сегментом, а також сприяв би ефективній промоції України.

\section{Література:}

1. Бодрухіна Т. А., Манич Н. С. Медіа конвергентність і нові медіа як тренд сучасної журналістики. Мас-медіа України на зламі епох: реалї та перспективи розвитку: матеріали всеукр. наук.-практ. інтернет-конф. (Старобільськ, 20-21 березня 2018 р.). Старобільськ, 2018. C. $100-103$.

2. Стратонова Н.О. Нові медіа сьогодні: стан та перспективи. Сучасні проблеми гуманітаристики: світоглядні пошуки, комунікативні та педагогічні стратегії: матеріали VII всеукр. наук.практ. конф. (Рівне, 7 грудня 2017 р.). Рівне, 2017. С. 100-103.

3. Manovich L.Z. The Language of New Media. MIT Press, 2001. P. 49-63. 